\title{
Nationality, Gender, Age, and Body Mass Index Influences on Vitamin D Concentration among Elderly Patients and Young Iraqi and Jordanian in Jordan
}

\author{
Hanan Al-Horani, ${ }^{1}$ Wael Abu Dayyih, ${ }^{1}$ Eyad Mallah, ${ }^{1}$ Mohammed Hamad, ${ }^{2}$ \\ Mohammad Mima, ${ }^{1}$ Riad Awad, ${ }^{1}$ and Tawfiq Arafat ${ }^{1}$ \\ ${ }^{1}$ Faculty of Pharmacy and Medical Sciences, University of Petra, Amman 00962, Jordan \\ ${ }^{2}$ College of Sciences and Health Professions, King Saud Bin Abdulaziz University for Health Sciences, Jeddah, Saudi Arabia
}

Correspondence should be addressed to Wael Abu Dayyih; wabudayyih@uop.edu.jo

Received 17 November 2015; Revised 10 February 2016; Accepted 23 February 2016

Academic Editor: Anita H. Corbett

Copyright ( $) 2016$ Hanan Al-Horani et al. This is an open access article distributed under the Creative Commons Attribution License, which permits unrestricted use, distribution, and reproduction in any medium, provided the original work is properly cited.

\begin{abstract}
Vitamin D is necessary for maintaining and regulating calcium levels; thus, insufficiency of vitamin D increases the risk of many chronic diseases. This study aimed to examine vitamin D levels among Jordanian and Iraqi volunteers and find the relation between vitamin D level and lipid profile patients. Vitamin D levels were evaluated using enzyme-linked immunosorbent assay. For young healthy group subjects, vitamin D levels were $20.60 \pm 5.94 \mathrm{ng} / \mathrm{mL}$ for Jordanian and $27.59 \pm 7.74 \mathrm{ng} / \mathrm{mL}$ for Iraqi. Vitamin D concentrations for young males and females were $25.82 \pm 8.33 \mathrm{ng} / \mathrm{mL}$ and $21.95 \pm 6.39 \mathrm{ng} / \mathrm{mL}$, respectively. Females wearing hijab were $20.87 \pm 6.45 \mathrm{ng} / \mathrm{mL}$, while uncovered females were $23.55 \pm 6.04 \mathrm{ng} / \mathrm{mL}$. For $>40$ years Iraqi subjects, vitamin $\mathrm{D}$ level for healthy was $29.78 \pm 9.49 \mathrm{ng} / \mathrm{mL}$ and $23.88 \pm 7.93 \mathrm{ng} / \mathrm{mL}$ for hyperlipidemic subjects. Vitamin D levels for overweight and obese healthy groups were significantly higher $(P<0.050)$ than those for the hyperlipidemic patients groups. Vitamin $\mathrm{D}$ levels for males were significantly higher than females and were significantly higher for healthy than those hyperlipidemic Iraqi patients. These findings showed that vitamin D levels are affected by age, nationality, gender, and health statues and highlight the importance of vitamin D supplementation for groups with low levels particularly old, hijab wearing females, and hyperlipidemic groups.
\end{abstract}

\section{Introduction}

Vitamin D is a fat soluble hormone that plays essential role in calcium homeostasis and mineralization of bones [1]. Vitamin $\mathrm{D}$ is unique, in terms of its metabolism and physiologic features. Human dependence on both endogenous syntheses (activation through exposure to ultraviolet light) accounts for about $90 \%$ of vitamin D (vitamin D3) and exogenous sources (diet, primarily fortified foods) to meet biological requirements (vitamins D2 and D3) [2-4].

Vitamins D3 (cholecalciferol) and D2 (ergocalciferol) are metabolized in an identical manner in the liver to 25-hydroxyvitamin D [5], by the enzyme cytochrome P450 (vitamin D 25-hydroxylases) to 25-hydroxyvitamin D3, which is the most abundant form of vitamin $\mathrm{D}$ in the circulation. Further hydroxylation of 25-hydroxyvitamin D to $1,25(\mathrm{OH}) 2 \mathrm{D}$ (active vitamin $\mathrm{D}$ ) by the $1 \alpha$-hydroxylase enzyme occurs in the kidney [6]. A circulation of approximately $10-15$ days halflife of 25(OH)D [7] makes it the ideal measure for vitamin D, although the concentration of $25(\mathrm{OH}) \mathrm{D}$ in the serum was 8$60 \mathrm{ng} / \mathrm{mL}$ or $20-150 \mathrm{nmol} / \mathrm{L}$ [7].

Many studies reported that vitamin D low levels negatively affect bone mineralization causing rickets in children and osteomalacia in adults $[4,8]$. In addition, vitamin D insufficiency is associated with other diseases; chronic kidney disease (CKD) gives rise to secondary hyperparathyroidism (SHPT) which can lead to loss of bone density and elevated rates of fracture in renal patients [9], common cancers [3], autoimmune disorders [10, 11], multiple sclerosis [12], cardiovascular disease [13], lung function, and asthma [14]. Also, epidemiological studies show that low blood levels of 25-hydroxyvitamin D $(25(\mathrm{OH}) \mathrm{D}$, a marker of vitamin D 
status), are linked with an increased risk of type 2 diabetes [14].

Besides, higher levels of $25(\mathrm{OH}) \mathrm{D}$ are associated with a healthier lipid profile $[15,16]$. However, its levels were found to be low in subjects with hypertriglyceridemia and hypercholesterolemia [16]. These studies however may be unable to differentiate the causation from association because of the possible uncontrolled confusing and inverse causation.

The growing data from studies conducted on young adults, elderly persons, and youth in different countries showed that vitamin D deficiency is not recognized and is not a predominant health problem [17]. Vitamin D status varies among countries according to latitude, dietary intake of fish and liver oil, season, and skin pigmentation. Higher $25(\mathrm{OH}) \mathrm{D}$ levels in Northern Europe compared with Southern Europe have only been found in elderly people. In adolescents, $25(\mathrm{OH}) \mathrm{D}$ levels are higher in the south of Europe than in the northern parts of Europe $[18,19]$.

In Middle East countries, high variation in serum $25(\mathrm{OH}) \mathrm{D}$ levels was revealed. The lowest level of $3.6 \mathrm{ng} / \mathrm{mL}$ $(9 \mathrm{nmol} / \mathrm{mL})$ was seen in a study conducted on older persons in Saudi Arabia [20]. Mallah et al. reported a strong correlation between the levels of $25(\mathrm{OH}) \mathrm{D}$ and clothing in Jordanian women [21]. Also very high rates of vitamin D insufficiency found in women of child-bearing age living in Beijing and Hong Kong were detected [22]. A lower serum $25(\mathrm{OH}) \mathrm{D}$ level was measured in Tunisia with lower mean level of veiled compared to nonveiled women [23]. In other African countries, studies showed adequate or even high mean serum 25(OH)D levels [24, 25].

Although Oceania has a very sunny climate, studies from Australia, New Zealand, and pacific islands detected low mean 25(OH)D levels (below $20 \mathrm{ng} / \mathrm{mL}$ ) and large seasonal variation was observed in volunteers in Vercargill, Dunedin, and New Zealand [26]. In USA, Ginde and team in 2009 conducted one of the largest representative samples available which is the National Health and Nutrition Examination Survey (NHANES). It showed that mean serum 25(OH)D levels were $19.9 \mathrm{ng} / \mathrm{mL}: 12.1 \mathrm{ng} / \mathrm{mL}$ in men and $19.8 \mathrm{ng} / \mathrm{mL}$ in women [27].

The current study seeks to determine vitamin D serum levels among healthy human volunteers living in Jordan by measuring serum levels of $25(\mathrm{OH}) \mathrm{D}$ and to examine the effect of nationality and gender on vitamin $\mathrm{D}$ status. In addition, we aimed to find an association between $25(\mathrm{OH}) \mathrm{D}$ levels with lipid profile results by determining $25(\mathrm{OH}) \mathrm{D}$ serum levels among hyperlipidemia Iraqi out-patients in Jordan.

\section{Materials and Methods}

2.1. Study Population. This study was conducted in April 2014 in Jordan. Three hundred and ninety subjects have been enrolled in this study: 195 young (18-30 years) apparently healthy Jordanian and Iraqi subjects and 195 (>40 years) hyperlipidemic Iraqi subjects. Of the 390 subjects, $26.5 \%$ were Jordanian and $73.5 \%$ were Iraqi. As for the gender, males represent $50.25 \%$ and females were $49.75 \%$. In addition, females were subdivided into two groups, first group (50.8\%) wearing hijab (hijab is a veil that covers head, arms, and chest) and second group (49.2\%) without hijab wearing modernized western style clothes.

The study protocol and the case report form were approved by the research committee (December 2013) at the Faculty of Pharmacy, University of Petra, Amman, Jordan. The case report form (CRF) was used to gather demographics, body mass index (BMI), dress style, vitamin D supplements hypolipidemic medication intake, and type of food intake. Females were categorized according to their dress style, hijab (covering all body parts except the face and hands) and western dress style. Subjects taking vitamin D supplements or under hypolipidemic medications were excluded.

2.2. Blood Sampling and Laboratory Analysis. Case report forms were filled by the subjects before blood sampling. Blood samples were collected using $10 \mathrm{~mL}$ syringes, transferred into $10 \mathrm{~mL}$ plane test tube, stood for clotting for 5-10 minutes, and then centrifuged (Hermle Z320, Hermle labor technique, Germany) at $5000 \mathrm{rpm}$ for 5 minutes. Serum was collected in a separate tube and stored at $-70^{\circ} \mathrm{C}$ until analysis.

2.3. Measurement of Vitamin D. Quantitative colorimetric immunoenzymatic determination of $25(\mathrm{OH})$ vitamin $\mathrm{D}$ concentrations in human plasma level was developed by using vitamin D ELISA kit (Diametra, Milano, Italy). The kit is a competitive solid phase enzyme-linked immunosorbent assay (ELISA). Samples were analyzed according to the manufacturer guidelines.

2.4. Vitamin D Classifications. Vitamin D levels were classified into 3 major groups according to the classification of the Institute of Medicine (IOM) [28, 29] as follows:

(1) sufficient (>30 ng/mL);

(2) insufficient $(20-30 \mathrm{ng} / \mathrm{mL})$;

(3) deficient $(<20 \mathrm{ng} / \mathrm{mL})$.

2.5. Data Analysis. Data from 390 subjects were expressed as mean \pm SD and statistically analyzed using SPSS v. 19.0 for Windows Software Package (SPSS Inc., Chicago, IL, USA). Analytical procedures include correlation analysis to analyze demographic and clinical factors associated with vitamin D levels after logarithmic transformation. The probability value of $P<0.050$ was considered significant.

\section{Results}

3.1. Vitamin D Levels of University of Petra Students. Table 1 summarizes the age and the body mass index (BMI) of the first group subjects (195 young subjects (18-30 years)); 103 subjects were Jordanian (51.46\% males, $29.13 \%$ females wearing hijab, and $19.42 \%$ females wearing western style clothing) and 92 were Iraqi $(51.10 \%$ males, $28.26 \%$ covered females, and $20.65 \%$ uncovered females). The impact of nationality, gender, and dress style on vitamin D levels is illustrated in Table 2, in which $32.6 \%$ of Iraqis having sufficient, $51.0 \%$ 
TABLE 1: Demographics data (age and body mass index) of all participants $(n=390)$.

\begin{tabular}{|c|c|c|c|}
\hline \multirow[t]{2}{*}{ Parameter } & $\begin{array}{l}\text { University of Petra students } \\
\qquad(N=195)\end{array}$ & $\begin{array}{l}\text { Old Iraqi healthy individuals } \\
\text { at Ibn Alhaytham Hospital } \\
\qquad(N=78)\end{array}$ & $\begin{array}{l}\text { Old Iraqi hyperlipidemic patients } \\
\text { at Ibn Alhaytham Hospital } \\
\qquad(N=117)\end{array}$ \\
\hline & Mean \pm SD & Mean \pm SD & Mean \pm SD \\
\hline \multicolumn{4}{|l|}{ Total } \\
\hline Age (years) & $21.51 \pm 2.81$ & $54.31 \pm 10.30$ & $54.89 \pm 9.39$ \\
\hline BMI $\left(\mathrm{kg} /\left(\mathrm{m}^{2}\right)\right)$ & $24.01 \pm 4.12$ & $27.80 \pm 4.21$ & $27.79 \pm 4.94$ \\
\hline \multicolumn{4}{|l|}{ Males } \\
\hline Age (years) & $21.82 \pm 3.04$ & $54.92 \pm 10.22$ & $53.84 \pm 8.96$ \\
\hline BMI $\left(\mathrm{kg} /\left(\mathrm{m}^{2}\right)\right)$ & $25.43 \pm 4.43$ & $28.53 \pm 4.21$ & $27.94 \pm 4.93$ \\
\hline \multicolumn{4}{|l|}{ Total females } \\
\hline Age (years) & $21.19 \pm 2.53$ & $54.01 \pm 10.51$ & $57.28 \pm 10.02$ \\
\hline BMI $\left(\mathrm{kg} /\left(\mathrm{m}^{2}\right)\right)$ & $22.51 \pm 3.17$ & $27.39 \pm 4.23$ & $27.74 \pm 5.01$ \\
\hline \multicolumn{4}{|l|}{ Uncovered females } \\
\hline Age (years) & $21.03 \pm 1.81$ & $54.64 \pm 10.20$ & $55.56 \pm 9.70$ \\
\hline $\operatorname{BMI}\left(\mathrm{kg} /\left(\mathrm{m}^{2}\right)\right)$ & $21.79 \pm 2.79$ & $27.31 \pm 4.00$ & $26.56 \pm 4.99$ \\
\hline \multicolumn{4}{|l|}{ Covered females } \\
\hline Age (years) & $21.27 \pm 2.94$ & $56.45 \pm 10.91$ & $58.65 \pm 10.25$ \\
\hline $\operatorname{BMI}\left(\mathrm{kg} /\left(\mathrm{m}^{2}\right)\right)$ & $23.00 \pm 3.37$ & $28.64 \pm 4.76$ & $28.20 \pm 5.03$ \\
\hline
\end{tabular}

TABLE 2: Distributions of participants from the University of Petra according to gender and nationality.

\begin{tabular}{|c|c|c|c|c|c|c|}
\hline & \multicolumn{2}{|c|}{ Sufficient $>30$} & \multicolumn{2}{|c|}{ Insufficient 20-30 } & \multicolumn{2}{|c|}{ Deficient $<20$} \\
\hline & Number & $\%$ & Number & $\%$ & Number & $\%$ \\
\hline \multicolumn{7}{|l|}{ Jordanian } \\
\hline Males & 4 & $7.55 \%$ & 27 & $50.94 \%$ & 22 & $41.51 \%$ \\
\hline Total females & 4 & $8.00 \%$ & 24 & $48.00 \%$ & 22 & $44.00 \%$ \\
\hline Females covered & 1 & $3.33 \%$ & 14 & $46.67 \%$ & 15 & $50.00 \%$ \\
\hline Females uncovered & 3 & $15.00 \%$ & 10 & $50.00 \%$ & 7 & $35.00 \%$ \\
\hline \multicolumn{7}{|l|}{ Iraqi } \\
\hline Males & 25 & $53.19 \%$ & 18 & $38.30 \%$ & 4 & $8.51 \%$ \\
\hline Total females & 5 & $11.11 \%$ & 29 & $64.44 \%$ & 11 & $24.44 \%$ \\
\hline Females covered & 1 & $3.85 \%$ & 17 & $65.38 \%$ & 8 & $30.77 \%$ \\
\hline Females uncovered & 4 & $21.05 \%$ & 12 & $63.16 \%$ & 3 & $15.79 \%$ \\
\hline
\end{tabular}

having insufficient, and $16.4 \%$ having deficient levels of vitamin D compared to $7.7 \%, 49.5 \%$, and $42.7 \%$ for Jordanian, respectively.

Herein, Figure 1 showed that there was a significant $(P<$ $0.050)$ difference in vitamin $\mathrm{D}$ mean level between the total Jordanians $(20.60 \pm 5.94 \mathrm{ng} / \mathrm{mL})$ and the total Iraqis $(27.59 \pm$ $7.74 \mathrm{ng} / \mathrm{mL}$ ). Also, Iraqi females showed significant higher vitamin D levels than Jordanian females $(24.16 \pm 6.06 \mathrm{ng} / \mathrm{mL}$ versus $19.92 \pm 6.06 \mathrm{ng} / \mathrm{mL}$, resp.; $P<0.050)$. Young Iraqi covered females showed higher $(23.12 \pm 6.34 \mathrm{ng} / \mathrm{mL})$ levels than those of young Jordanian covered female $(18.91 \pm 5.97 \mathrm{ng} / \mathrm{mL})$ $(P<0.050)$. Same pattern $(P<0.050)$ was observed between young Jordanian western style wearing females and young Iraqi uncovered females $(21.52 \pm 6.02 \mathrm{ng} / \mathrm{mL}$ versus $25.58 \pm 5.49 \mathrm{ng} / \mathrm{mL}$, resp.) (Figure 1). Significant differences $(P<0.050)$ in vitamin $\mathrm{D}$ levels were detected between the total male students $(25.82 \pm 8.33 \mathrm{ng} / \mathrm{mL}$ and the total female students $(21.95 \pm 6.39 \mathrm{ng} / \mathrm{mL}$. In contrast, vitamin $\mathrm{D}$ levels between Iraqi and Jordanian male students showed no significant difference.

3.2. Vitamin D Levels for Healthy and Hyperlipidemic Iraqi Individuals at Ibn Alhaytham Hospital. 195 (>40 years) Iraqi subjects; 78 healthy subjects; and 117 hyperlipidemic patients were enrolled in the second part of the study. The age of 78 healthy subjects ranged from 40 to 72 years with the average of $54.3 \pm 10.3$ years and body mass index (BMI) ranged from 18 to $37 \mathrm{~kg} / \mathrm{m}^{2}$, with the of average of $27.8 \pm 4.2 \mathrm{~kg} / \mathrm{m}^{2}$ (Table 1 ). Besides, the age of 117 hyperlipidemic patients ranged from 40 to 75 years, with the average of $54.89 \pm 9.39$ years, and body mass index (BMI) ranged from 17 to $37 \mathrm{~kg} / \mathrm{m}^{2}$, with the average of $27.79 \pm 4.94 \mathrm{~kg} / \mathrm{m}^{2}$ (Table 1). Further classification is also found in Table 1 . 
TABLE 3: Distributions of participants from Ibn Alhaytham Hospital according to gender, health status, and vitamin D levels.

\begin{tabular}{|c|c|c|c|c|c|c|}
\hline & \multicolumn{2}{|c|}{ Sufficient $>30$} & \multicolumn{2}{|c|}{ Insufficient 21-29 } & \multicolumn{2}{|c|}{ Deficient $<20$} \\
\hline & Number & $\%$ & Number & $\%$ & Number & $\%$ \\
\hline \multicolumn{7}{|l|}{ Healthy } \\
\hline Males & 14 & $51.85 \%$ & 11 & $40.74 \%$ & 2 & $7.41 \%$ \\
\hline Total females & 22 & $43.14 \%$ & 21 & $41.18 \%$ & 8 & $15.69 \%$ \\
\hline Females covered & 9 & $39.13 \%$ & 8 & $34.78 \%$ & 6 & $26.09 \%$ \\
\hline Females uncovered & 13 & $46.43 \%$ & 13 & $46.43 \%$ & 2 & $7.14 \%$ \\
\hline \multicolumn{7}{|l|}{ Patient } \\
\hline Males & 16 & $19.75 \%$ & 42 & $51.85 \%$ & 23 & $28.40 \%$ \\
\hline Total females & 7 & $19.44 \%$ & 18 & $50.00 \%$ & 11 & $30.56 \%$ \\
\hline Females covered & 2 & $10.00 \%$ & 12 & $60.00 \%$ & 6 & $30.00 \%$ \\
\hline Females uncovered & 5 & $31.25 \%$ & 6 & $37.50 \%$ & 5 & $31.25 \%$ \\
\hline
\end{tabular}

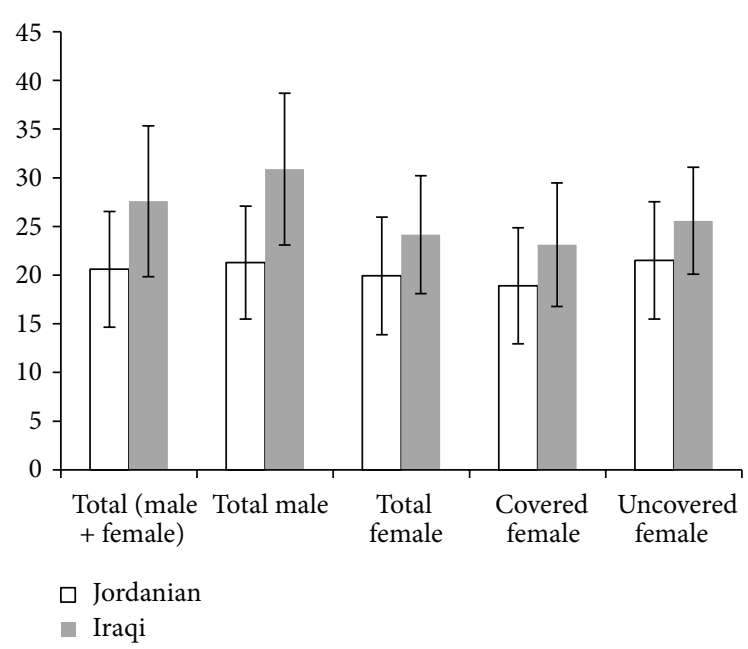

FIGURE 1: Mean value of vitamin D levels in $\mathrm{ng} / \mathrm{mL}$ in University of Petra students according to their nationality.

The data in Table 3 illustrated that $46.15 \%$ of healthy subjects had sufficient vitamin D levels (36 subjects; 14 males, 9 hijab wearing females, and 13 western style wearing females), $41.03 \%$ subjects had insufficient vitamin D levels (32 subjects; 11 males, 8 covered females, and 13 uncovered females), and 10 healthy old subjects (12.82\%) had deficient vitamin D level ( 2 males, 6 covered females, and 2 uncovered females). Also, about half of the hyperlipidemic patients (51.28\%) had vitamin D level between 21 and $29 \mathrm{ng} / \mathrm{mL}$; while $29.06 \%$ were with vitamin D deficiency. The rest $19.66 \%$ were with sufficient vitamin D level (Table 3).

In the current study, healthy individuals and hyperlipidemic patients were classified according to BMI into 3 major groups: normal $\left(18.5-24.9 \mathrm{~kg} / \mathrm{m}^{2}\right)$, overweight $\left(25-29.9 \mathrm{~kg} / \mathrm{m}^{2}\right)$, and obese $\left(>30 \mathrm{~kg} / \mathrm{m}^{2}\right)$. Of the healthy individuals $(n=78), 16.8 \%$ were normal, $42.4 \%$ were overweight, and $40.8 \%$ were obese. Of the 32 obese, and according to vitamin D levels, it was found that $15.3 \%$ of them had sufficient, $19.2 \%$ had insufficient, and $6.4 \%$ had deficient vitamin D levels, while in hyperlipidemic individuals ( $n=117)$ 8.5\% were normal, $25.6 \%$ were overweight, and
$41.8 \%$ were obese. In 49 of the obese hyperlipidemic patients, it was found that $3.4 \%$ of them had sufficient vitamin D level, $18.8 \%$ had insufficient vitamin D level, and $19.6 \%$ had deficient vitamin $\mathrm{D}$ level.

Furthermore, Table 4 showed the differences in vitamin D levels between the healthy and hyperlipidemic Iraqi subjects. A significant difference $(P<0.050)$ was detected between Iraqi healthy males $(32.18 \pm 10.21 \mathrm{ng} / \mathrm{mL})$ and females $(28.55 \pm$ $8.96 \mathrm{ng} / \mathrm{mL}$ ).

Herein, comparison between healthy and hyperlipidemic patients based on BMI was done and vitamin D mean level for the normal BMI healthy individuals was $30.32 \pm$ $9.42 \mathrm{ng} / \mathrm{mL}$, while that of hyperlipidemic patients was $26.78 \pm$ $9.05 \mathrm{ng} / \mathrm{mL}$. Also, vitamin D level for the overweight BMI healthy individuals was $31.82 \pm 11.43 \mathrm{ng} / \mathrm{mL}$, and that of hyperlipidemic patients was $25.47 \pm 7.81 \mathrm{ng} / \mathrm{mL}$ (Table 4 ). A significant difference $(P<0.050)$ between obese subjects of the two groups was detected; vitamin D mean level of the obese BMI category healthy individuals was $27.51 \pm$ $6.79 \mathrm{ng} / \mathrm{mL}$, whereas that of hyperlipidemic patients was $20.96 \pm 6.42 \mathrm{ng} / \mathrm{mL}$.

The study finding revealed that vitamin $\mathrm{D}$ level was decreased with age in both healthy and hyperlipidemic patients as shown in Table 4; vitamin $\mathrm{D}$ mean levels for healthy individuals were $37.41 \pm 9.09 \mathrm{ng} / \mathrm{mL}$ in the age $40-50$ years, $31.05 \pm 4.54 \mathrm{ng} / \mathrm{mL}$ in the age $51-60$ years, and $21.51 \pm$ $3.41 \mathrm{ng} / \mathrm{mL}$ in the ages $>60$ years. Similarly, in hyperlipidemic individuals of the age 40-50 years, vitamin D mean level was $25.87 \pm 9.13 \mathrm{ng} / \mathrm{mL}$, while that of the age $>60$ years was $18.69 \pm 5.18 \mathrm{ng} / \mathrm{mL}$. It is interesting that for all age groups vitamin $\mathrm{D}$ mean levels were significantly higher in healthy compared to hyperlipidemic individuals.

\section{Discussion}

The finding of this study revealed that vitamin D levels are affected by many factors such as nationality, gender, sex, BMI, physical activity, and lifestyle and this was reported previously in Middle East rejoin [30-35].

Also, physical activity and lifestyle are important factors in determining vitamin $\mathrm{D}$ level. Herein, Figure 1 showed that there was a significant $(P<0.050)$ difference in vitamin 
TABLE 4: Mean value of vitamin $\mathrm{D}$ levels in $\mathrm{ng} / \mathrm{mL}$ for $>40$ years of age in healthy and hyperlipidemic Iraqi volunteers.

\begin{tabular}{lccc}
\hline Category & $\begin{array}{c}\text { Healthy } \\
\text { Vitamin D }(\mathrm{ng} / \mathrm{mL})\end{array}$ & $\begin{array}{c}\text { Patient } \\
\text { Vitamin D }(\mathrm{ng} / \mathrm{mL})\end{array}$ & $P$ value \\
\hline Total & $29.78 \pm 9.49(N=78)$ & $23.88 \pm 7.93(N=117)$ & $<0.0001^{*}$ \\
Total males & $32.18 \pm 10.21(N=27)$ & $24.03 \pm 8.01(N=81)$ & $23.53 \pm 7.84(N=36)$ \\
Total females & $28.55 \pm 8.96(N=51)$ & $26.78 \pm 9.05(N=29)$ & $0.0224^{*}$ \\
Normal BMI weight & $30.32 \pm 9.42(N=13)$ & $25.47 \pm 7.81(N=38)$ & 0.2208 \\
Overweight $(N=33)$ & $31.82 \pm 110.43(N=33)$ & $20.96 \pm 6.42(N=49)$ & $0.0077^{*}$ \\
Obese & $27.51 \pm 6.79(N=32)$ & $25.87 \pm 9.13(N=43)$ & $0.0002^{*}$ \\
40-50 years & $37.41 \pm 9.09(N=29)$ & $26.34 \pm 6.34(N=39)$ & $0.0001^{*}$ \\
51-60 years & $31.05 \pm 4.54(N=24)$ & $18.96 \pm 5.18(N=35)$ & $0.0125^{*}$ \\
Over 60 years & $21.53 \pm 3.41(N=25)$ & &
\end{tabular}

*Significant $(P$ value $<0.050)$.

D mean level between the total Jordanian and total Iraqi. Also, Iraqi females showed significant higher vitamin D levels than Jordanian females $(P<0.050)$. Young Iraqi covered females showed higher levels of vitamin $D$ than those of young Jordanian covered female $(P<0.050)$. Same pattern $(P<0.050)$ was observed between young Jordanian western style wearing females and young Iraqi uncovered females (Figure 1). The reason behind those results might be the different lifestyles and physical activity $[13,36]$. Clothes are a main blocker to sun exposure and therefore $25(\mathrm{OH}) \mathrm{D}$ synthesis and status; in this study, we found that females with western style wearing have higher levels of $25(\mathrm{OH}) \mathrm{D}$ than those wearing hijab. Sun exposure to uncovered face and hands as in hijab dressed females is not enough for vitamin D synthesis. In addition, the differences in $25(\mathrm{OH}) \mathrm{D}$ levels among covered or uncovered Iraqis or Jordanian females might be related to the texture of clothing; some clothes such as wool, silk, and polyester are blocking UV radiation greater than cotton and linin. In addition, colors may affect the absorption of UV radiation (black is higher absorber than white) $[37,38]$. Also, food consumption like dairy product is of the main factors that affect $25(\mathrm{OH}) \mathrm{D}$ levels. Moreover, this variation may be related to the latitude of the city or country the participants come from; however, such factor is not addressed in the study since all participants were living in Jordan at the time of the study. Healthy lifestyle is usually associated with sufficient vitamin D serum levels, while the low physical activity is associated with low $25(\mathrm{OH}) \mathrm{D}$ levels $[39,40]$. In contrast, vitamin D levels between Iraqi and Jordanian male students showed no significant difference, and this may result from the similarity in lifestyles, physical activity, and diet between both groups.

Regardless of the nationality, significant differences $(P<$ 0.050 ) in vitamin D levels were detected between total male students and total female students, which might be explained by the outdoor activity of males, that is, the sun light exposure duration which is more than that of females, and also may be due to the use of sun block by females [41] and breast-feeding in nursing mothers [42]. Excess adipose tissue of females compared with males has been suggested as a causal factor to lower $25(\mathrm{OH}) \mathrm{D}$ concentrations in females [43].
The age and BMI of the 195 ( $>40$ years) Iraqi healthy and hyperlipidemic subjects from Ibn Alhaytham Hospital enrolled in the second part of the study are shown in Table 1 and their vitamin D levels are presented in Table 3. Furthermore, Table 4 showed the differences in vitamin D levels between the healthy and hyperlipidemic Iraqi subjects. A significant difference $(P<0.050)$ was detected between Iraqi healthy males and females.

As vitamin $\mathrm{D}$ is a fat soluble hormone, thus adipose tissue might be a site of sequestration of vitamin $\mathrm{D}$, storing and subsequently lowering circulating levels of $25(\mathrm{OH}) \mathrm{D}[1,3]$. And because normal and overweight subjects have adipose tissue less than that of obese subjects, they might show elevation in the availability of vitamin D $[44,45]$ and this is in accordance with the results revealed in this study.

The inverse relationship between circulating levels of $25(\mathrm{OH}) \mathrm{D}$ with risk biomarkers and high lipid profile was detected by many studies [46, 47]. Herein, comparison between healthy and hyperlipidemic patients based on BMI was done and vitamin D mean level for the normal BMI healthy individuals and hyperlipidemic patients was also evaluated. Vitamin D level for the overweight BMI healthy individuals and that for hyperlipidemic patients was presented in Table 4. These findings are consistent with Brock et al., who reported that body mass index (BMI) $>30 \mathrm{~kg} / \mathrm{m}^{2}$ is one of the major factors that affect vitamin D levels [48].

In addition, age is essential factor that affects vitamin D levels like obesity, gender, and diseases. Generally, elder people are susceptible to vitamin D deficiency due to many risk factors, not only due to reduced skin production of vitamin D with age but also due to decreased sunlight exposure, decreased dietary intake, reduced skin thickness, impaired intestinal absorption, and diminished hydroxylation in the liver and kidney $[49,50]$.

The study finding revealed that vitamin $\mathrm{D}$ level was decreased with age in both healthy and hyperlipidemic patients as shown in Table 4 and it is interesting that for all age groups vitamin $\mathrm{D}$ mean levels were significantly higher in healthy compared to hyperlipidemic individuals.

The elevation of plasma vitamin $\mathrm{D}$ levels in the body is dependent on the vitamin $\mathrm{D}$ hydroxylase, vitamin $\mathrm{D}$ 
binding protein (group-specific component; GC), and the inactivation by cytochromes P450 CYP24 (or 25(OH)D-24hydroxylase) and CYP3A4. Consequently, single nucleotide polymorphism (SNP) markers in the genes, namely, CYP2R1 and GC, might be a reason for different vitamin D levels in healthy Caucasians [51, 52]. And this could be one of the reasons that lead to variation in vitamin levels among different populations. Further research is required in order to clarify the genetic architecture underlying $25(\mathrm{OH}) \mathrm{D}$ plasma concentrations among Jordanians and Iraqis.

However, the incidence of vitamin D insufficiency and deficiency in Arab people is multifactorial involving gender, age, obesity, clothing, cultural behaviors, skin pigmentation, vitamin $\mathrm{D}$, calcium supplements, sun exposure, and polymorphism of vitamin D receptors $[28,53-56]$.

\section{Conclusion}

The current study showed that there was a significant difference in vitamin $\mathrm{D}$ concentrations between the total Jordanian and total Iraqi students and there were insignificant differences between Jordanian male and Iraqi students. Vitamin D levels also were significantly different among total Jordanian female and total Iraqi female students and the same results were detected for Jordanian hijab wearing female compared to Iraqi hijab wearing female students. A significant difference was found between Jordanian western styles wearing female students compared to Iraqi uncovered female students.

In addition, overweight and obese BMI categories showed a significant difference between healthy individuals and hyperlipidemic patients though; normal BMI category showed no significant difference between the two groups. In this study, vitamin D levels for healthy individuals were higher than vitamin $\mathrm{D}$ levels for hyperlipidemic patients in the three age categories. Hyperlipidemia is associated with decreased vitamin $\mathrm{D}$ concentrations through an unknown mechanism. Further studies are needed to replicate these data in larger populations and to elucidate the mechanisms involved in this association. Also, it is necessary to take supplements especially for those who have low plasma $25(\mathrm{OH}) \mathrm{D}$ levels related to SNPs markers of inactivating enzymes and/or vitamin $\mathrm{D}$ binding protein

\section{Competing Interests}

The authors declare that there are no competing interests.

\section{Acknowledgments}

The authors would like to thank all volunteers for their cooperation and also Ibn Alhaytham Hospital.

\section{References}

[1] C. M. Weaver, "Vitamin D, calcium homeostasis, and skeleton accretion in children," Journal of Bone and Mineral Research, vol. 22, supplement 2, pp. V45-V49, 2007.
[2] S. Chakrabarty, H. Wang, L. Canaff, G. N. Hendy, H. Appelman, and J. Varani, "Calcium sensing receptor in human colon carcinoma: interaction with $\mathrm{Ca}^{2+}$ and 1,25-dihydroxyvitamin $\mathrm{D}_{3}$," Cancer Research, vol. 65, no. 2, pp. 493-498, 2005.

[3] K.-C. Chiang, C.-N. Yeh, M.-F. Chen, and T. C. Chen, "Hepatocellular carcinoma and vitamin D: a review," Journal of Gastroenterology and Hepatology, vol. 26, no. 11, pp. 1597-1603, 2011.

[4] M. F. Holick, "Medical progress: vitamin D deficiency," New England Journal of Medicine, vol. 357, no. 3, pp. 266-281, 2007.

[5] J. G. Haddad Jr. and T. J. Hahn, "Natural and synthetic sources of circulating 25-hydroxyvitamin D in man," Nature, vol. 244, pp. 515-527, 1973.

[6] M. Garg, J. S. Lubel, M. P. Sparrow, S. G. Holt, and P. R. Gibson, "Review article: vitamin D and inflammatory bowel diseaseestablished concepts and future directions," Alimentary Pharmacology \& Therapeutics, vol. 36, no. 4, pp. 324-344, 2012.

[7] G. Jones, "Pharmacokinetics of vitamin D toxicity," American Journal of Clinical Nutrition, vol. 88, no. 2, pp. 582S-586S, 2008.

[8] M. F. Holick and T. C. Chen, "Vitamin D deficiency: a worldwide problem with health consequences," The American Journal of Clinical Nutrition, vol. 87, no. 4, pp. 1080S-1086S, 2008.

[9] A. S. Dusso, "Kidney disease and vitamin D levels: 25-hydroxyvitamin D, 1,25-dihydroxyvitamin D, and VDR activation," Kidney International Supplements, vol. 1, no. 4, pp. 136-141, 2011.

[10] J. J. Cannell, R. Vieth, J. C. Umhau et al., "Epidemic influenza and vitamin D," Epidemiology and Infection, vol. 134, no. 6, pp. 1129-1140, 2006.

[11] P. T. Liu, S. Stenger, H. Li et al., “Toll-like receptor triggering of a vitamin D-mediated human antimicrobial response," Science, vol. 311, no. 5768, pp. 1770-1773, 2006.

[12] G. Giovannoni and G. Ebers, "Multiple sclerosis: the environment and causation," Current Opinion in Neurology, vol. 20, no. 3, pp. 261-268, 2007.

[13] T. L. Larose, Y. Chen, C. A. Camargo Jr., A. Langhammer, P. Romundstad, and X.-M. Mai, "Factors associated with vitamin D deficiency in a Norwegian population: the HUNT Study," Journal of Epidemiology and Community Health, vol. 68, no. 2, pp. 165-170, 2014.

[14] T. L. Larose, A. Langhammer, Y. Chen, C. A. Camargo Jr., P. Romundstad, and X. M. Mai, "Serum 25-hydroxyvitamin D levels and lung function in adults with asthma: the HUNT Study," The European Respiratory Journal, vol. 45, pp. 1019-1026, 2015.

[15] R. Jorde and G. Grimnes, "Vitamin D and metabolic health with special reference to the effect of vitamin D on serum lipids," Progress in Lipid Research, vol. 50, no. 4, pp. 303-312, 2011.

[16] D. Martins, M. Wolf, D. Pan et al., "Prevalence of cardiovascular risk factors and the serum levels of 25-hydroxyvitamin D in the United States: data from the Third National Health and Nutrition Examination Survey," Archives of Internal Medicine, vol. 167, no. 11, pp. 1159-1165, 2007.

[17] C. M. Gordon, K. C. DePeter, H. A. Feldman, E. Grace, and S. J. Emans, "Prevalence of vitamin D deficiency among healthy adolescents," Archives of Pediatrics and Adolescent Medicine, vol. 158, no. 6, pp. 531-537, 2004.

[18] N. Laktasic-Zerjavic, M. Korsic, Z. Crncevic-Orlic, Z. Kovac, O. Polasek, and D. Soldo-Juresa, "Vitamin D status, dependence on age, and seasonal variations in the concentration of vitamin $\mathrm{D}$ in Croatian postmenopausal women initially screened for osteoporosis," Clinical Rheumatology, vol. 29, no. 8, pp. 861-867, 2010. 
[19] R. P. J. van der Wielen, L. C. P. G. M. de Groot, W. A. van Staveren et al., "Serum vitamin D concentrations among elderly people in Europe," The Lancet, vol. 346, no. 8969, pp. 207-210, 1995.

[20] A. A. Mishal, "Effects of different dress styles on vitamin D levels in healthy young Jordanian women," Osteoporosis International, vol. 12, no. 11, pp. 931-935, 2001.

[21] E. M. Mallah, M. F. Hamad, M. A. Elmanaseer et al., "Plasma concentrations of 25-hydroxyvitamin D among Jordanians: effect of biological and habitual factors on vitamin D status," BMC Clinical Pathology, vol. 11, article 8, 2011.

[22] J. Woo, C. W. K. Lam, J. Leung et al., "Very high rates of vitamin $\mathrm{D}$ insufficiency in women of child-bearing age living in Beijing and Hong Kong," British Journal of Nutrition, vol. 99, no. 6, pp. 1330-1334, 2008.

[23] N. Meddeb, H. Sahli, M. Chahed et al., "Vitamin D deficiency in Tunisia," Osteoporosis International, vol. 16, no. 2, pp. 180-183, 2005.

[24] S. Mehta, D. J. Hunter, F. M. Mugusi et al., "Perinatal outcomes, including mother-to-child transmission of HIV, and child mortality and their association with maternal vitamin D status in tanzania," Journal of Infectious Diseases, vol. 200, no. 7, pp. 1022-1030, 2009.

[25] T. J. Aspray, L. Yan, and A. Prentice, "Parathyroid hormone and rates of bone formation are raised in perimenopausal rural Gambian women," Bone, vol. 36, no. 4, pp. 710-720, 2005.

[26] J. E. P. Rockell, C. M. Skeaff, B. J. Venn, S. M. Williams, and T. J. Green, "Vitamin D insufficiency in New Zealanders during the winter is associated with higher parathyroid hormone concentrations: implications for bone health?" New Zealand Medical Journal, vol. 121, no. 1286, pp. 75-84, 2008.

[27] A. A. Ginde, M. C. Liu, and C. A. Camargo Jr., "Demographic differences and trends of vitamin D insufficiency in the US population, 1988-2004," Archives of Internal Medicine, vol. 169, no. 6, pp. 626-632, 2009.

[28] M. F. Holick, N. C. Binkley, H. A. Bischoff-Ferrari et al., "Evaluation, treatment, and prevention of vitamin D deficiency: an endocrine society clinical practice guideline," Journal of Clinical Endocrinology and Metabolism, vol. 96, no. 7, pp. 19111930, 2011.

[29] C. Annweiler, G. Allali, P. Allain et al., "Vitamin D and cognitive performance in adults: a systematic review," European Journal of Neurology, vol. 16, no. 10, pp. 1083-1089, 2009.

[30] N. M. Al-Daghri, K. M. Alkharfy, A. Al-Othman et al., "Effect of gender, season, and vitamin $\mathrm{D}$ status on bone biochemical markers in Saudi diabetes patients," Molecules, vol. 17, no. 7, pp. 8408-8418, 2012.

[31] A. Al-Othman, S. Al-Musharaf, N. M. Al-Daghri et al., "Effect of physical activity and sun exposure on vitamin D status of Saudi children and adolescents," BMC Pediatrics, vol. 12, article 92, 2012.

[32] A. Al-Othman, S. Al-Musharaf, N. M. Al-Daghri et al., "Tea and coffee consumption in relation to vitamin $\mathrm{D}$ and calcium levels in Saudi adolescents," Nutrition Journal, vol. 11, no. 1, article 56, 2012.

[33] B. Hamilton, J. Grantham, S. Racinais, and H. Chalabi, "Vitamin D deficiency is endemic in Middle Eastern sportsmen," Public Health Nutrition, vol. 13, no. 10, pp. 1528-1534, 2010.

[34] N. A. Meguid, A. F. Hashish, M. Anwar, and G. Sidhom, "Reduced serum levels of 25-hydroxy and 1,25-dihydroxy vitamin D in Egyptian children with autism," Journal of Alternative and Complementary Medicine, vol. 16, no. 6, pp. 641-645, 2010.
[35] S. Racinais, B. Hamilton, C. K. Li, and J. Grantham, "Vitamin $\mathrm{D}$ and physical fitness in Qatari girls," Archives of Disease in Childhood, vol. 95, no. 10, pp. 854-865, 2010.

[36] M. E. Miettinen, L. Kinnunen, J. Leiviskä et al., "Association of serum 25-hydroxyvitamin D with lifestyle factors and metabolic and cardiovascular disease markers: populationbased cross-sectional study (FIN-D2D)," PLoS ONE, vol. 9, no. 7, Article ID e100235, 2014

[37] S. Davis, L. Capjack, N. Kerr, and R. Fedosejevs, "Clothing as protection from ultraviolet radiation: which fabric is most effective?" International Journal of Dermatology, vol. 36, no. 5, pp. 374-379, 1997.

[38] R. M. Neer, "The evolutionary significance of vitamin D, skin pigment, and ultraviolet light," American Journal of Physical Anthropology, vol. 43, no. 3, pp. 409-416, 1975.

[39] O. Engelsen, "The relationship between ultraviolet radiation exposure and vitamin D status," Nutrients, vol. 2, no. 5, pp. 482495, 2010.

[40] D. M. Freedman, S.-C. Chang, R. T. Falk et al., "Serum levels of vitamin $\mathrm{D}$ metabolites and breast cancer risk in the prostate, lung, colorectal, and ovarian cancer screening trial," Cancer Epidemiology, Biomarkers \& Prevention, vol. 17, no. 4, pp. 889894, 2008.

[41] A. W. Norman, "Minireview: vitamin D receptor: new assignments for an already busy receptor," Endocrinology, vol. 147, no. 12, pp. 5542-5548, 2006.

[42] M. F. Holick, "Resurrection of vitamin D deficiency and rickets," The Journal of Clinical Investigation, vol. 116, no. 8, pp. 20622072, 2006.

[43] R. M. van Dam, M. B. Snijder, J. M. Dekker et al., "Potentially modifiable determinants of vitamin D status in an older population in the Netherlands: the Hoorn Study," The American Journal of Clinical Nutrition, vol. 85, no. 3, pp. 755-761, 2007.

[44] A. Poobalan, L. Aucott, W. C. S. Smith et al., "Effects of weight loss in overweight/obese individuals and long-term lipid outcomes-a systematic review," Obesity Reviews, vol. 5, no. 1, pp. 43-50, 2004.

[45] C. L. Rock, J. A. Emond, S. W. Flatt et al., "Weight loss is associated with increased serum 25-hydroxyvitamin D in overweight or obese women," Obesity, vol. 20, no. 11, pp. 22962301, 2012.

[46] K. Y. Z. Forrest and W. L. Stuhldreher, "Prevalence and correlates of vitamin D deficiency in US adults," Nutrition Research, vol. 31, no. 1, pp. 48-54, 2011.

[47] D. H. Kim, S. Sabour, U. N. Sagar, S. Adams, and D. J. Whellan, "Prevalence of Hypovitaminosis D in Cardiovascular Diseases (from the National Health and Nutrition Examination Survey 2001 to 2004)," The American Journal of Cardiology, vol. 102, no. 11, pp. 1540-1544, 2008.

[48] K. Brock, R. Cant, L. Clemson, R. S. Mason, and D. R. Fraser, "Effects of diet and exercise on plasma vitamin D (25(OH)D) levels in Vietnamese immigrant elderly in Sydney, Australia," The Journal of Steroid Biochemistry and Molecular Biology, vol. 103, no. 3-5, pp. 786-792, 2007.

[49] D. D. Bikle, "Vitamin D insufficiency/deficiency in gastrointestinal disorders," Journal of Bone and Mineral Research, vol. 22, no. 2, pp. V50-V54, 2007.

[50] M. Gasscon-Barre, “The vitamin D 25-hydroxylase," in Vitamin D, D. Feldman, J. W. Pike, and F. H. Glorieux, Eds., pp. 47-68, Elsevier Academic Press, Boston, Mass, USA, 2nd edition, 2005. 
[51] F.-X. Bu, L. Armas, J. Lappe et al., "Comprehensive association analysis of nine candidate genes with serum 25-hydroxy vitamin D levels among healthy Caucasian subjects," Human Genetics, vol. 128, no. 5, pp. 549-556, 2010.

[52] J. J. McGrath, S. Saha, T. H. J. Burne, and D. W. A. Eyles, "A systematic review of the association between common single nucleotide polymorphisms and 25-hydroxyvitamin D concentrations," The Journal of Steroid Biochemistry and Molecular Biology, vol. 121, no. 1-2, pp. 471-477, 2010.

[53] S. Al-Musharaf, A. Al-Othman, N. M. Al-Daghri et al., "Vitamin D deficiency and calcium intake in reference to increased body mass index in children and adolescents," European Journal of Pediatrics, vol. 171, no. 7, pp. 1081-1086, 2012.

[54] M. Y. Elsammak, A. A. Al-Wosaibi, A. Al-Howeish, and J. Alsaeed, "Vitamin D deficiency in Saudi Arabs," Hormone and Metabolic Research, vol. 42, no. 5, pp. 364-368, 2010.

[55] F. L. Weng, J. Shults, M. B. Leonard, V. A. Stallings, and B. S. Zemel, "Risk factors for low serum 25-hydroxyvitamin D concentrations in otherwise healthy children and adolescents," The American Journal of Clinical Nutrition, vol. 86, no. 1, pp. 150158, 2007.

[56] R. J. Wood and J. C. Fleet, "The genetics of osteoporosis: vitamin D receptor polymorphisms," Annual Review of Nutrition, vol. 18, pp. 233-258, 1998. 

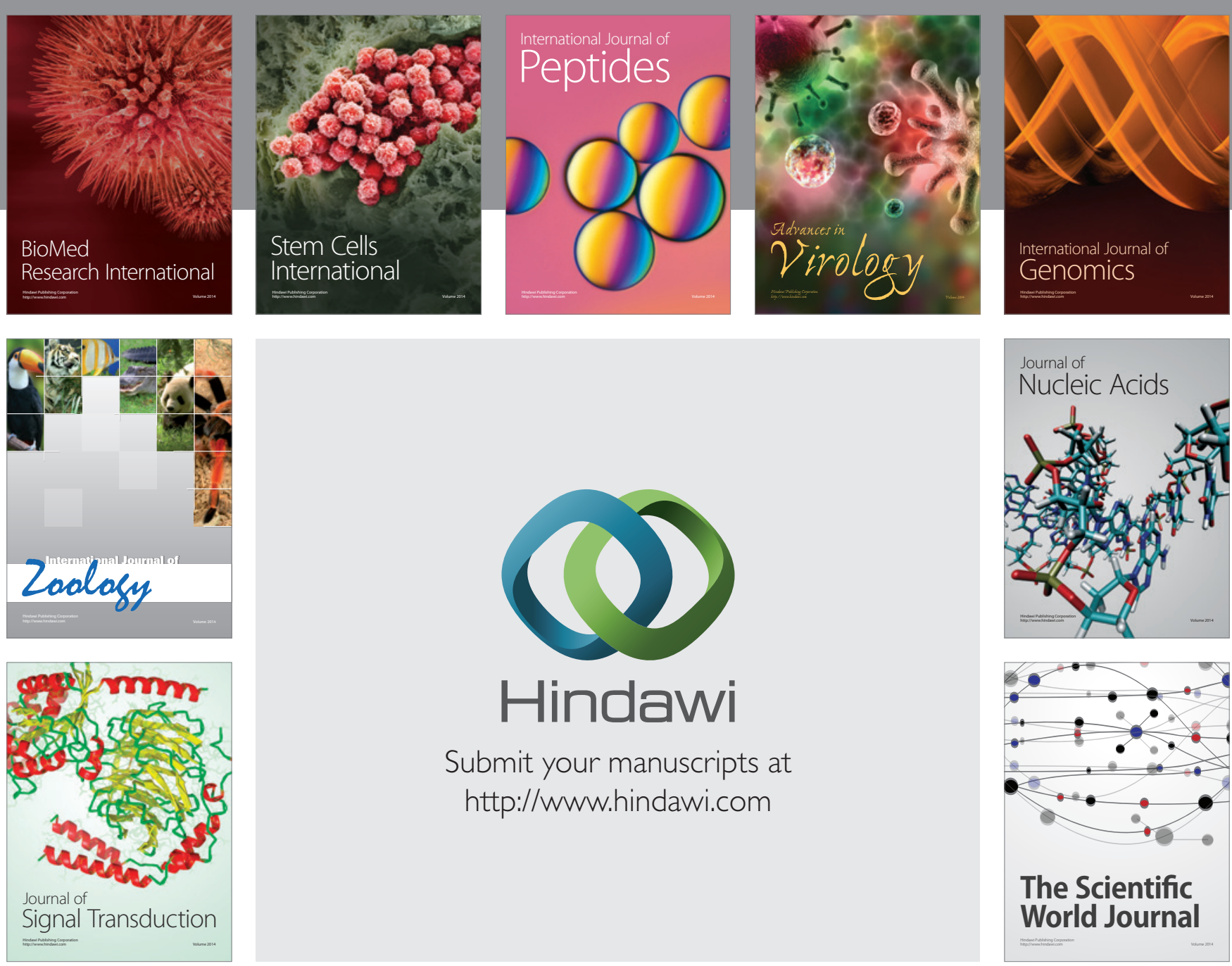

Submit your manuscripts at

http://www.hindawi.com
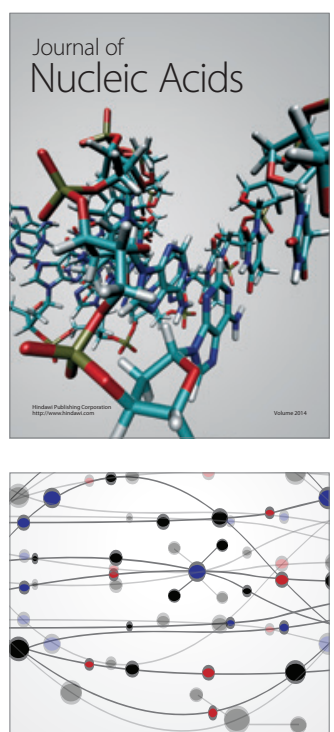

The Scientific World Journal
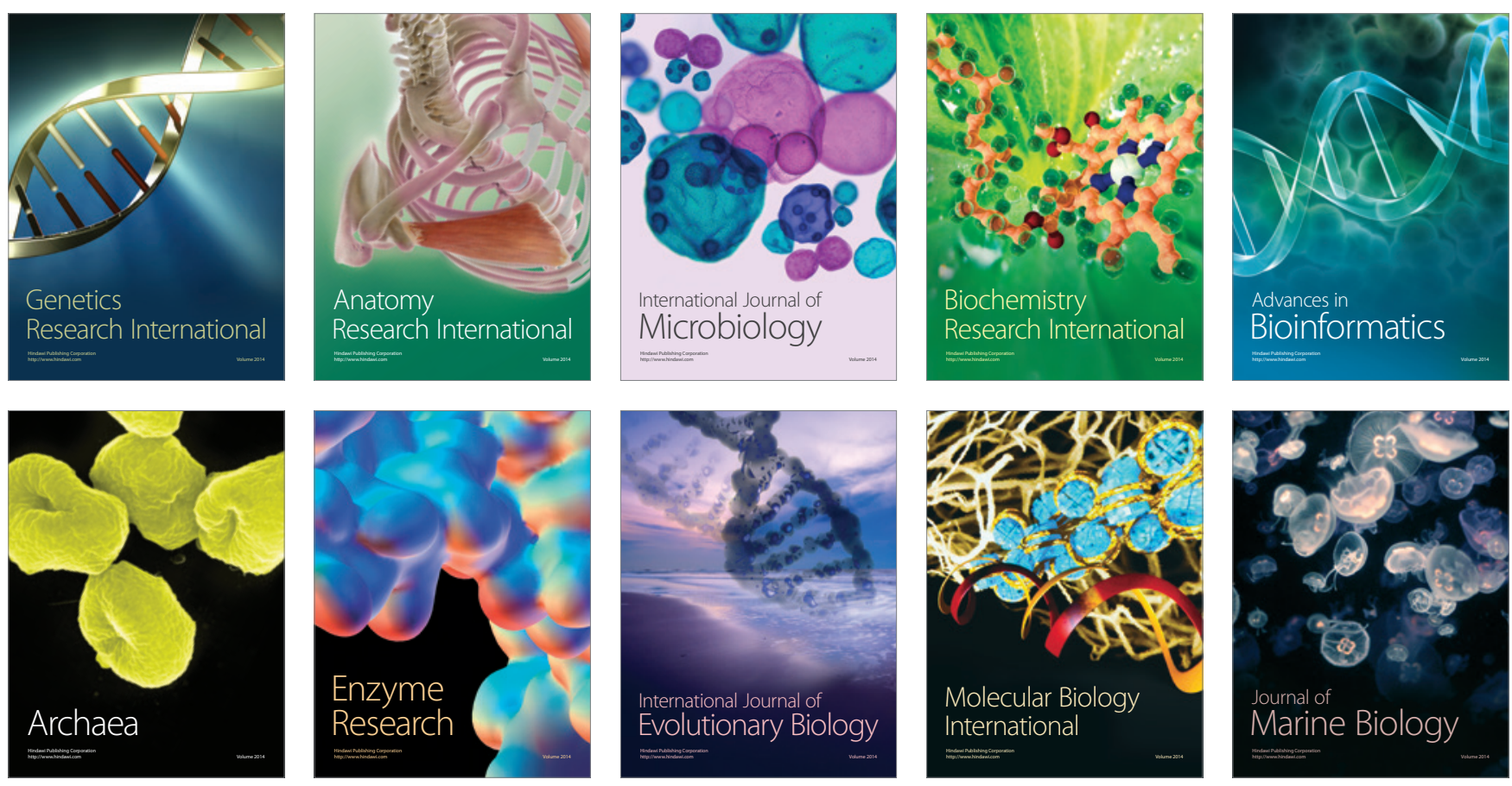